\title{
PERANCANGAN CHASSIS TYPE TUBULAR SPACE FRAME UNTUK KENDARAAN LISTRIK
}

\author{
Tito Shantika, Eka Taufiq Firmansjah dan Ilham Naufan \\ Jurusan Teknik Mesin Institut Teknologi Nasional Bandung \\ Jl. PHH Mustofa no.23 Bandung, \\ e-mail: tshantika@itenas.ac.id
}

\begin{abstract}
Vehicle is the important think to get the better live for peoples of sociaty. Currently the development of vehicles is increasing rapidly, especially vehicles that use friendly energy for enviroment such as electrical energy. The electric vehicles have been used for commercial cars as well as for competitions. The race vehicle is required to develop new technologies in the particular vehicle. The electrical Vehicle Researces has been carried out include the systems such as drive train, Cassis, frame, batree, system control etc, however in this paper will be discuss design of electric vehicles Frame for Competition. The proces design will be accordance with the rules competition, there is dimensions, weight, power of vehicle etc. the vehicle specification requarenment will be created concept design, then embodiment design and detail design, theres will be figure out the strength and ergonomics frames to satisfy the safety criteria. Results of design obtained dimensions of frame 1800x800x1000 mm, $35.7 \mathrm{~kg}$ of weight, and material frame JIS G 3445 STKM 11 is obtained for static load load while stress of maximum impact load is $91.6 \mathrm{Mpa}$, deflection $0.61 \mathrm{~mm}$ and safety factor 2, 1.
\end{abstract}

Keywords : Electical Vehicle, chassis, tubular space frame, frame.

\section{PENDAHULUAN}

Kendaraan merupakan sarana transportasi yang sangat penting penggunaannya pada saat ini. Perkembangan kendaraan saat ini begitu pesat dengan digunakannya beberapa alternatif energi untuk menghasilkan daya pada kendaraan tersebut. Kendaraaan dengan menggunakan energi listrik mengalami perkembangan yang cukup besar dimana semakin beralihnya kendaraaan dengan sumber energi yang menggunakan Ignition Combustion Engine Vehicle (ICEVs) menjadi kendaraan dengan menggunakan energi listrik atau electric vehicle (EVs) seperti pada Gambar 1 [1].

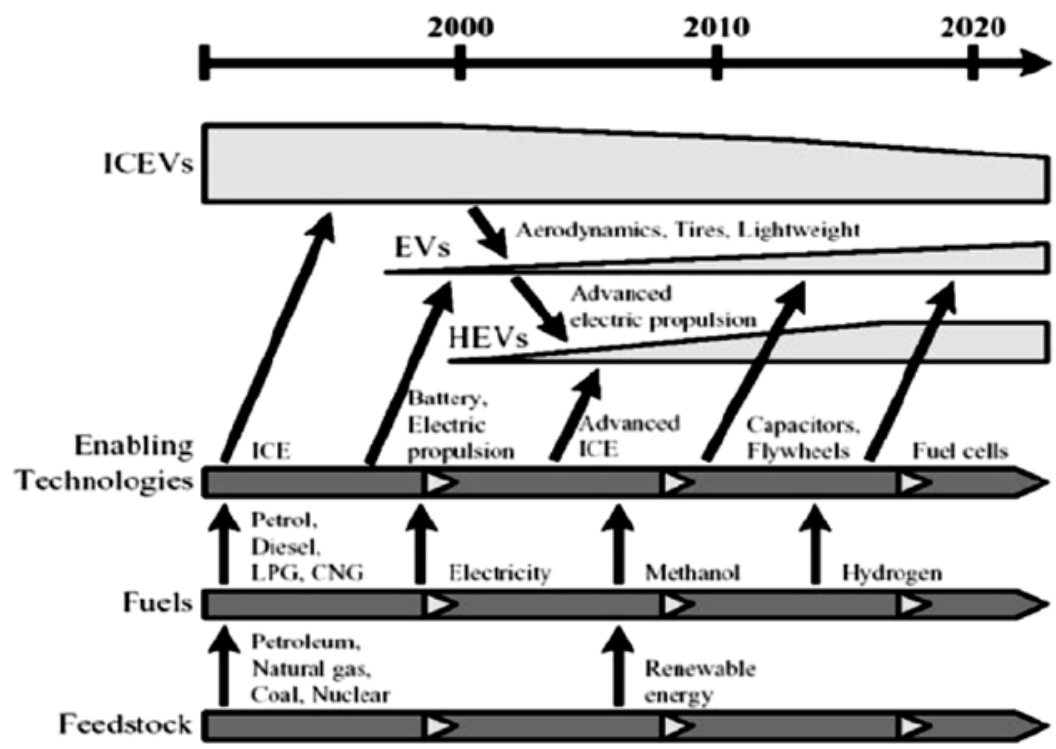

Gambar 1. Tren perkembangan EVs dan HEVs[1]

Perkembangan kendaraan listrik akan sangat pesat dengan adanya kompetisi untuk membuat kendaraan yang layak dipasarkan. Salah satu kompetisi yang diadakan di Indonesia yaitu Kontes Mobil Listrik Indonesia yang merupakan kompetisi tingkat mahasiswa. Sehingga perlu adanya rancang bangun kendaraan listrik yang dapat digunakan dalam ajang tersebut. 
Kendaraan listrik diperlukan rancang bangun beberapa komponen pada kendaraan listrik tersebut, seperti chassis, suspensi, drive train, sistem kontrol dan sebagainya. Salah satu komponen yang sangat penting adalah chassis yang dibutuhkan untuk menopang sebuah beban yang bekerja pada kendaraan. Sehingga tujuan penelitian ini yaitu merancang chassis/frame kendaraan listrik perancangan yang dipergunakan untuk lomba/kompetisi. Chassis yang akan dirancang merupakan jenis tubular space frame karena menurut Keith, (2009) chassis tersebut mempunyai kekuatan luluhnya sangat bagus terutama pada sifat kekakuan torsional, ketahanan beban berat, dan beban impak [2].

\section{Chassis Kendaraan}

Chassis kendaraan merupakan rangka yang berfungsi sebagai penopang berat kendaraan, mesin penumpang, serta beban-beban lain. Biasanya chassis terbuat dari kerangka baja yang memegang body dan engine dari sebuah kendaraan. Saat proses manufaktur body kendaraan dibentuk sesuai dengan struktur chassis-nya. Chassis mobil biasanya terbuat dari logam atau pun komposit. Material tersebut harus memiliki kekuatan untuk menopang beban dari kendaraan. Chassis juga berfungsi untuk menjaga agar mobil tetap rigid atau kaku dan tidak mengalami bending menurut Fadila (2012)[3].

Ada beberapa jenis chassis tergantung pada jenis kendaraan dan kegunaannya. Tentunya masing-masing tersebut memiliki kekurangan dan kelebihan. Jenis-jenis chassis diantaranya adalah: Ladder frame yaitu dua batangan panjang yang menyokong kendaraan dan menyediakan dukungan yang kuat dari berat beban dan umumnya berdasarkan desain angkut [3]. Tubular space frame adalah chassis terbaik yang kekuatan luluhnya sangat bagus di perlindungan kekakuan torsional, ketahanan beban berat, dan beban impak. Monocoque merupakan satu kesatuan stuktur chassis dari bentuk kendaraannya sehingga chassis ini memiliki bentuk yang beragam yang menyesuaikan dengan body mobil. Aluminium space frame Aluminium Chassis Frame dibuat untuk menggantikan chassis baja monocoque karena untuk menghasilkan sebuah rangka yang ringan [3].

Menurut Andersson (2009) bahan yang paling banyak digunakan untuk chassis terutama jenis tubular space frame adalah jenis baja karena kuat, tangguh, mudah dibentuk dan murah. Salah satu jenis yang umum digunakan baja adalah baja ringan, yang memiliki kadar karbon rendah dan relatif lunak, mudah diproses dan murah [4]. Alternatif material yang lain yang populer untuk baja ringan adalah CrMo-4130, yang memiliki sifat kekuatan yang lebih baik, meskipun lebih rumit untuk memproduksinya. Kelebihan menggunakan baja adalah material tersebut sangat kuat dan tahan lama, sedangkan kekurangan adalah relatif berat dan tidak tahan karat seperti menurut Revserve (2013) [5].

\section{Regulasi Kendaraan}

Spesifikasi mobil yang dirancang harus sesuai dengan regulasi Kontes Mobil Listrik Indonesia dimana dimensi lebar mobil listrik adalah antara $120 \mathrm{s.d} 140 \mathrm{~cm}$, berat minimum mobil dan pengemudi adalah $170 \mathrm{~kg}$, daya total motor maksimum yang diijinkan $2 \mathrm{~kW}$. Dan untuk memenuhi faktor keselamatan saat berjalannya lomba berlangsung, mobil harus memiliki rollbar yang lebih tinggi minimal $5 \mathrm{~cm}$ dari helm pengemudi, serta spesifikasi rollbar adalah besi pipa berdiameter minimal 1 inc dengan ketebalan minimal $2 \mathrm{~mm}$ [6].

\section{Tegangan pada Struktur}

Tegangan adalah reaksi yang timbul pada suatu struktur yang mengalami pembebanan, dimana beban tersebut akan diteruskan ke semua bagian struktur. Menurut jenis pembebanan yang diberikan tegangan diklasifikasikan menjadi dua yaitu tegangan Normal dan tegangan Geser. Tegangan Normal adalah besar gaya tarik/tekan dibagi dengan luas penampang suatu benda. Tegangan tarik termasuk gaya persatuan luas. Tegangan geser, didefinisikan sebagai komponen tegangan dengan penampang melintang sebuah benda. Tegangan geser timbul dari gaya paralel ke 
penampang melintang tegangan normal, disisi lain, muncul dari komponen vector gaya tegak lurus dari penampang melintang bahan.

\section{Faktor Keamanan}

Faktor keamanan (Safety of factor) merupakan faktor yang diberikan kepada suatu desain konstruksi sebagai jaminan dalam proses desain. Harga Faktor keamanan yang diberikan harus lebih besar dari 1 (satu). Faktor keamanan didapatkan dari perbandingan tegangan Luluh (yield Strength) suatu material dengan tegangan yang terjadi (Actual Strength) pada suatu desain konstruksi tersebut. Menurut Dobrovolsky V., (1988) faktor keamanan diberikan kepada suatu desain biasanya berdasarkan jenis pembebanan yaitu Pembebanan Statis: 1,25 - 2, Pembebanan Dinamis : 2 - 3 dan Pembebanan Kejut : 3 - 5 [7].

Factor of Safety $=\frac{\text { Yield Strength }\left(\sigma_{y}\right)}{\text { Actual Strength }\left(\sigma_{\text {actual }}\right)}$

\section{Ergonomi}

Ergonomi adalah ilmu yang mempelajari mengenai sifat dan keterbatasan manusia yang digunakan untuk merancang sistem kerja, sehingga sistem tersebut dapat bekerja dengan baik. Dapat pula dikatakan bahwa aplikasi ilmu ergonomi adalah membentuk kondisi yang efektif, aman, sehat, nyaman dan efisien.

Ergonomi tidak terbatas hanya pada rancangan kursi yang baik atau meja yang ergonomis saja, melainkan jauh lebih luas, yakni merancang metode, alat dan sistem kerja sesuai dengan manusianya (pekerja) atau dikenal dengan istilah Human Centered Design. Karena manusia lahir dalam bentuk dan ukuran, adalah penting bahwa data antropometrik memberikan berbagai dimensi. Langkah-langkah dari manusia baik dipresentasikan sebagai distribusi normal, Ulman (2010). Data antropometri khas diberikan standar MIL - STD (Standar Militer) 1472F yang ditunjukkan pada Gambar 2 [8].
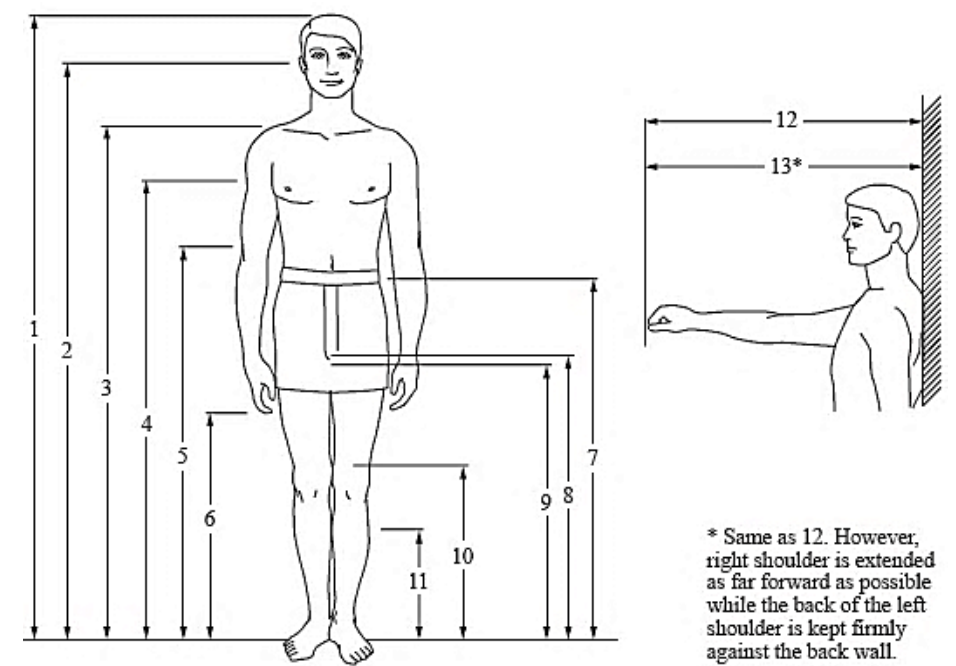

$$
\begin{aligned}
& \text { * Same as } 12 \text {. However, } \\
& \text { right shoulder is extended } \\
& \text { as far forward as possible } \\
& \text { while the back of the left } \\
& \text { shoulder is kept firmly } \\
& \text { against the back wall. }
\end{aligned}
$$

Gambar 2. Standar ukuran manusia (MIL-STD1472D) [8]

Perancangan chassis kendaraan dengan metode numerik bukan hal baru, beberapa peneliti banyak menggunakan alat analisis dengan menggunakan Finite Element Analysis (FEA) untuk mendapatkan desain yang baik, seperti Kiran Ghodvinde \& S. R. Wankhade, (2014) telah merancang chassis Chevy truck menggunakan perangkat lunak stress analysis Ansys untuk mendapatkan critical stress pada chassis tersebut. Pada chassis tersebut, chassis menunjukkan tegangan kritis pada sambungan dan berkurang tegangannya pada sisi yang lebih tebal, ketebalan 
plat sambungan dan panjang sambungan plat yang bervariasi. Hasil numerik menunjukkan bahwa tegangan pada elemen damping chassis dapat dikurangi dengan meningkatkan ketebalan diarea sisi tersebut [9].

\section{METODE PENELITIAN}

Perancangan dimulai dengan memahami regulasi mengenai spesifikasi kendaraan listrik selanjutnya ditentukan spesifikasi perancangan chassis kendaraan. Langkah selanjutnya membuat konsep chassis yang akan merujuk seperti pada teori Pahl \& Beitzt (1984) [10], dimana pada tahap ini mencari beberapa alternatif konsep kemudian dinilai dan dipilih menjadi satu konsep terbaik. Konsep terpilih akan diwujudkan dalam perancangan bentuk (Embodiment design) dimana telah mempertimbangkan menempatkan beberapa komponen yang ditopang oleh chassis, kemudian perancangan detail (detail design) chassis untuk menentukan dimensi maupun material dengan menggunakan perangkat lunak Solidworks. Hasil Perancangan harus memenuhi kriteria dimana $s f \geq 2$. Proses selanjutnya gambar pembuatan gambar teknik untuk dapat difabrikasi.
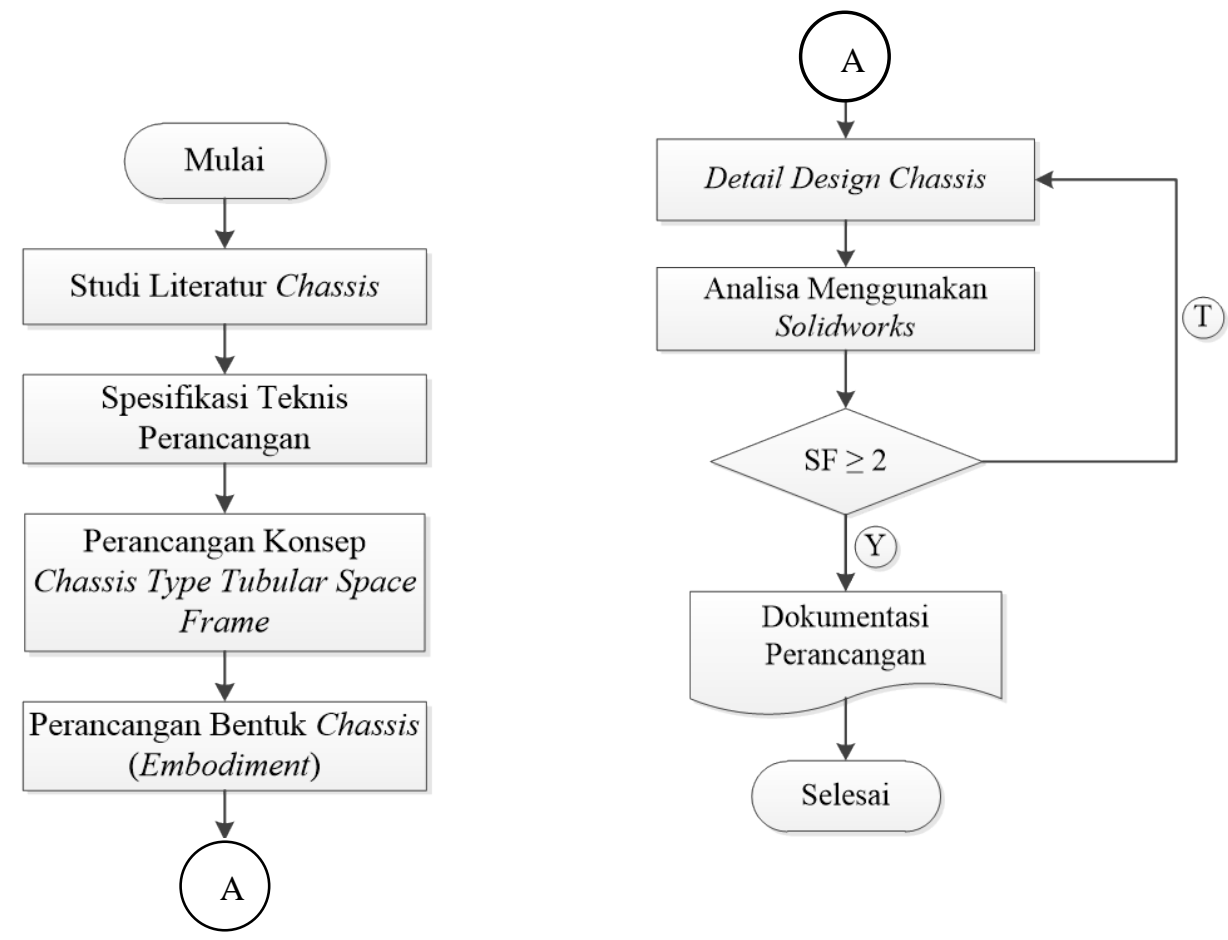

Gambar 3. Diagram alir proses perancangan

\section{HASIL DAN PEMBAHASAN}

\section{Spesifikasi Perancangan}

Spesifikasi perancangan chassis mobil listrik ini mengikuti regulasi perlombaan dan target yang akan dicapai dalam proses perancangan. Regulasi perlombaan yang dipakai adalah untuk perlombaan Kontes Mobil Listrik Indonesia. Spesifikasi perancangan adalah sebagai berikut:

$\begin{array}{ll}\text { Dimensi lebar } & : 120-140 \mathrm{~cm} \\ \text { Lebar maksimum kendaraan } & : 1300 \mathrm{~mm} \\ \text { Massa Minimum } & : 170 \mathrm{~kg} \\ \text { Daya Motor } & : \text { Maksimum } 2 \mathrm{~kW} \\ \text { Ukuran rollbar } & : 5 \mathrm{~cm} \text { di atas helm } \\ \text { Wheelbase } & : 1100 \mathrm{~mm} \\ \text { Suspensi } & : \text { Menggunakan } 4 \text { buah suspensi absorber } \\ \text { Kecepatan Maksimum } & : 60 \mathrm{~km} / \mathrm{jam}\end{array}$




\section{Perancangan Konsep Chassis}

Perancangan konsep chassis meliputi membuat sketsa chassis yaitu membuat skets chassis yang akan dirancang, kemudian proses pengukuran layout dimensi chassis yang akan dirancang dengan mengukur pengemudi saat berada pada kabin kendaraan agar memiliki ergonomi yang baik. Terdapat beberapa konsep varian chassis yang memungkinkan untuk direalisasikan seperti pada Gambar 4, namun perlu penilaian dengan pendekatan kualitatif seperti teori Pahl \& Beitzt (1984)[10], beberapa gambar konsep Gambar 4 kemudian dievaluasi dengan menggunakan tabel sesuai dengan kriteria evaluasi yang dilakukan seperti pada Tabel 1 di bawah untuk dapat dilakukan pemilihan konsep secara terukur.

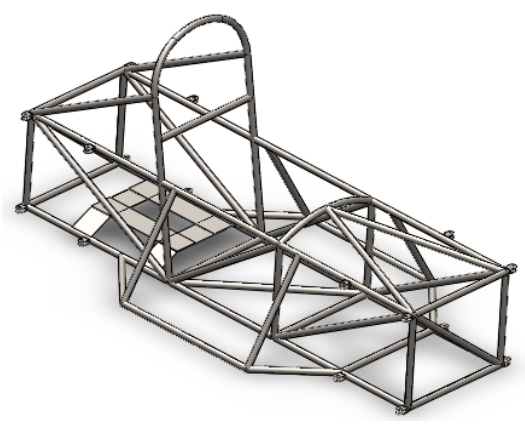

(a)

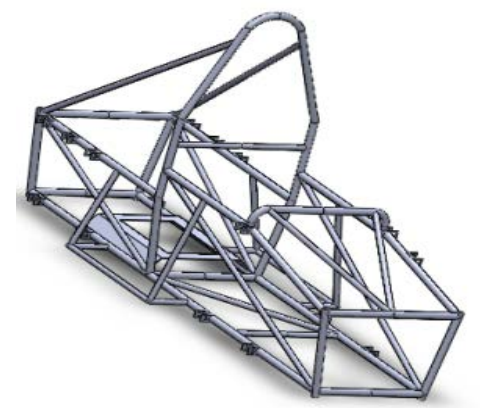

(c)

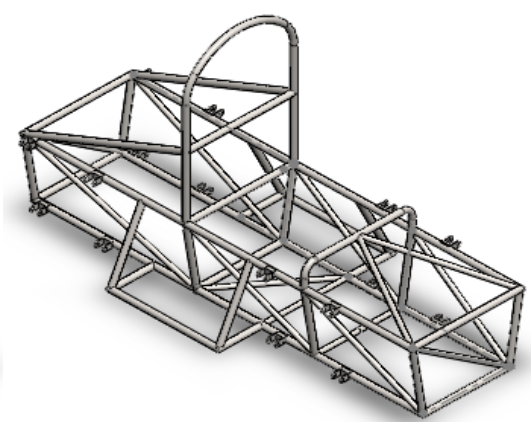

(b)

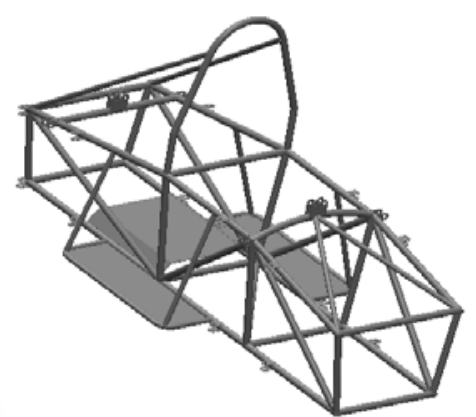

(d)

Gambar 4. Beberapa konsep varian chassis

Kriteria evaluasi dapat dilihat dari kemudahan memperoleh bahan, kemudahan pembuatan, jumlah komponen sedikit, ringan dan sebagainya maka dari hasil evaluasi berdasarkan bobot kriteria (OWV) konsep, maka dapat dipilih konsep pada varian 4 terlihat pada Tabel 1.

Tabel 1. Evaluasi Konsep

\begin{tabular}{|c|c|c|c|c|c|c|c|c|c|c|}
\hline \multirow{2}{*}{ No } & \multirow{2}{*}{ Kriteria Evaluasi } & \multirow{2}{*}{$\begin{array}{c}\text { Bobot } \\
\text { (W) }\end{array}$} & \multicolumn{2}{|c|}{ Konsep 1} & \multicolumn{2}{|c|}{ Konsep 2} & \multicolumn{2}{|c|}{ Konsep 3} & \multicolumn{2}{|c|}{ Konsep 4} \\
\hline & & & $\mathbf{W}$ & VW & $\mathbf{W}$ & VW & $\mathbf{W}$ & VW & $\mathbf{W}$ & VW \\
\hline 1 & Kemudahan memperoleh bahan & 0,1 & 5 & 0,5 & 5 & 0,5 & 5 & 0,5 & 5 & 0,5 \\
\hline 2 & Kemudahan dibuat & 0,15 & 5 & 0,75 & 4 & 0,6 & 4 & 0,6 & 4 & 0,6 \\
\hline 3 & Jumlah komponen sedikit & 0,1 & 4 & 0,4 & 3 & 0,3 & 5 & 0.5 & 5 & 0,5 \\
\hline 4 & Mudah dirakit & 0,15 & 5 & 0,75 & 4 & 0,6 & 3 & 0,45 & 5 & 0,75 \\
\hline 5 & Ringan & 0,2 & 3 & 0,6 & 4 & 0,8 & 5 & 1 & 5 & 1 \\
\hline 6 & Dimensi & 0,1 & 5 & 0,5 & 5 & 0,5 & 5 & 0,5 & 5 & 0,5 \\
\hline 7 & Aman & 0,2 & 5 & 1 & 5 & 1 & 5 & 1 & 5 & 1 \\
\hline & $\Sigma O W V$ & & & 4,5 & & 4,3 & & 4,55 & & 4,85 \\
\hline
\end{tabular}

\section{Perancangan Bentuk Chassis}

Perancangan bentuk chassis merupakan perancangan bentuk chassis dengan mempertimbangkan komponen-komponen yang terkait pada chassis tersebut, bentuk, berat maupun 
ukuran komponen yang ditopang oleh chassis dapat diperkirakan sesuai dengan kebutuhan kendaraan listrik, seperti baterai, suspensi, pengendara, motor listrik dan diferensial gear. Dari perancangan bentuk ini menghasilkan perkiraan ukuran maupun layout chassis yang memungkinkan untuk dapat di analisis sehingga mendapatkan ukuran sesungguhnya. Layout beberapa komponen yang ditopang oleh chassis dapat dilihat pada Gambar 5.

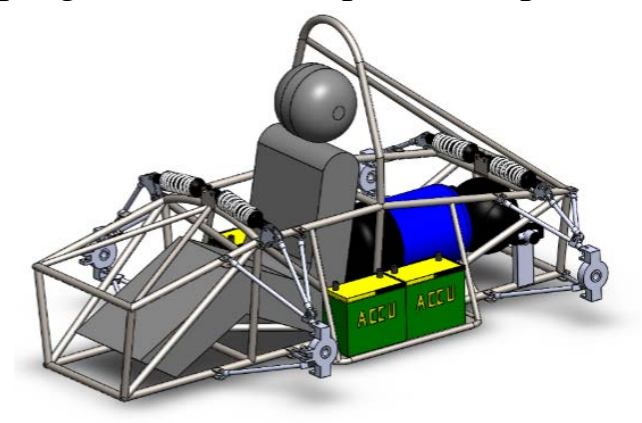

Gambar 5. Hasil perancangan bentuk Chassis

\section{Perancangan Detail Chassis Menggunakan Perangkat Lunak}

Perancangan detail merupakan perancangan untuk mendapatkan ukuran, dimensi dan material yang digunakan untuk fabrikasi. Perancangan detail chassis akan menggunakan perangkat lunak Solid Works, dimulai dengan membuat model analisis, kemudian proses meshing dan penentuan parameter beban-beban pada chassis dimana terdapat beban statis dan beban benturan. Langkah selanjutnya proses analisis tegangan untuk mendapatkan karakteristik chassis jika diberikan beban statis dan benturan tersebut. Pada proses analisis tegangan dilakukan beberapa kali untuk mendapatkan safety factor kurang dari 2.

\section{Pembebanan dan Tumpuan}

Beban-beban yang terjadi pada chassis antara lain beban statik diantaranya berat pengemudi sebesar $491 \mathrm{~N}$, berat baterai 196,2 $\mathrm{N}$, berat motor listrik 274,7 $\mathrm{N}$ dan berat differensial gear belakang sebesar 196,2 N, sedangkan untuk beban tumbukan yang terjadi diasumsikan terjadi pada pada $60 \mathrm{~km} / \mathrm{jam}$, dengan berat total kendaraan dan pengemudi $170 \mathrm{~kg}$ serta waktu saat bertumbukan yaitu 1 detik sebesar $2.822 \mathrm{~N}$. Tumpuan pada chassis berada pada mounting upper arm pada suspensi kendaraan dengan jenis tumpuan fix pada ke-empat suspensi kendaraan tersebut, seperti pada Gambar 6.

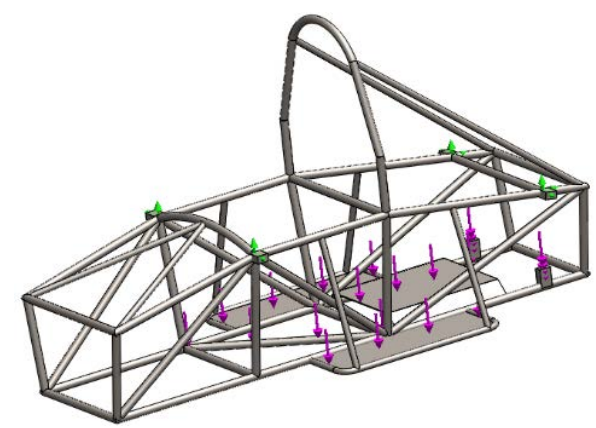

(a)

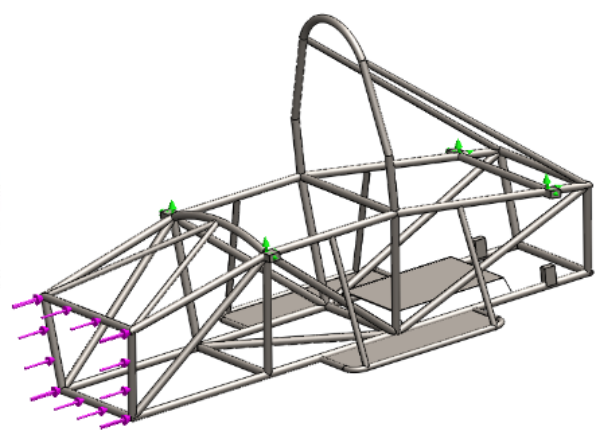

(b)

Gambar 6. Beban dan Tumpuan (a) Beban berat komponen, (b) Beban tumbukan

Hasil dari perancangan bentuk dapat diambil ukuran sementara yaitu panjang $1800 \mathrm{~mm}$, lebar $800 \mathrm{~mm}$ dan tinggi $1000 \mathrm{~mm}$, dengan material pipa berdiameter 25,4 dengan tebal 1,4 dan rollbar $2 \mathrm{~mm}$. Jenis material yang dipakai JIS G 3445 dengan spesifikasi STKM 11. Material tersebut mempunyai sifat mekanik Yield strength $=1,92 \times 10^{8} \mathrm{~N} / \mathrm{m}^{2}$, Tensile strength $=2,97 \times 10^{8}$ $\mathrm{N} / \mathrm{m}^{2}$, Elastic modulus $=2 \times 10^{11} \mathrm{~N} / \mathrm{m}^{2}$, Poisson's ratio $=0,29$, Mass density $=7.870 \mathrm{~kg} / \mathrm{m}^{3} \mathrm{dan}$ Shear modulus $=8 \times 10^{10} \mathrm{~N} / \mathrm{m}^{2}$. 
Dari data-data diatas maka proses analisis tegangan dapat dilakukan dengan perangkat lunak. Proses meshing pada pemodelan menggunakan software SolidWorks. Jenis mesh yang digunakan untuk stress analysis yaitu Beam Mesh dengan total 10.497 nodes dan total elemen 10.138 nodes.

\section{Stress Analysis Chassis untuk Beban Statik}

Hasil Stress Analysis didapatkan karakteristik chassis dengan pembebanan seperti yang telah dijelaskan diatas, seperti tegangan maksimum, defleksi maksimum dan safety factor.

Tegangan maksimum pada chassis dengan material JIS G 3445 adalah 53,4 N/mm² (Mpa) pada element 5187 atau terletak pada posisi pengelasan mounting suspensi (tumpuan). Sedangkan tegangan minimum yang terjadi pada chassis sebesar $0 \mathrm{~N} / \mathrm{mm}^{2}$ (Mpa) pada element 636, seperti terlihat pada Gambar 6a.

Pada Gambar 7b defleksi maksimum pada chassis dengan material JIS G 3445 sebesar 1,2 mm pada node 6884 atau terletak pada dudukan motor listrik. Sedangkan defleksi minimum yang didapat sebesar $0 \mathrm{~mm}$ pada node 135 .

Faktor keamanan maksimum pada chassis dengan material JIS G 3445 adalah 50 pada node 1 atau terletak pada posisi yang tidak terkena gaya sedikitpun. Sedangkan faktor keamanan minimum yang terjadi pada chassis sebesar 3,6 pada node 5185 sehingga material sangat baik untuk digunakan, seperti pada Gambar 7c.

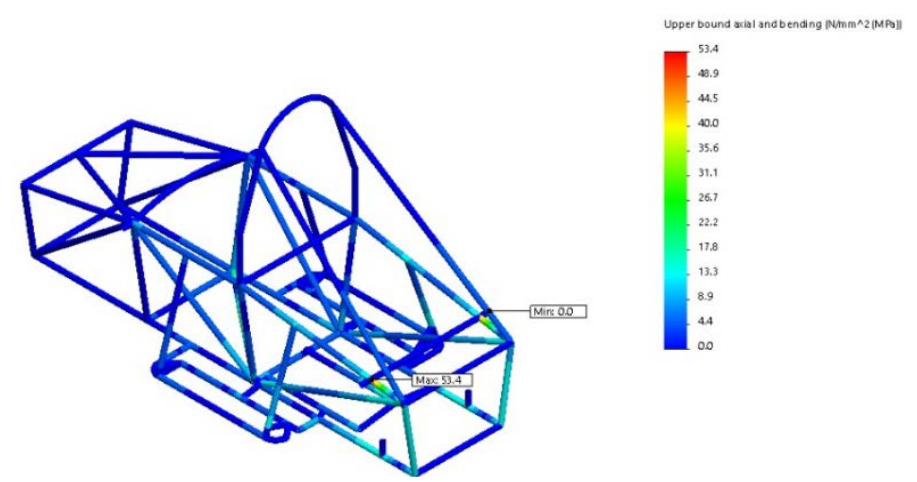

(a)

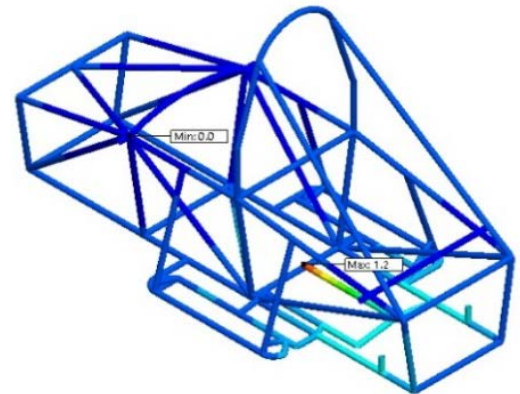

(b)

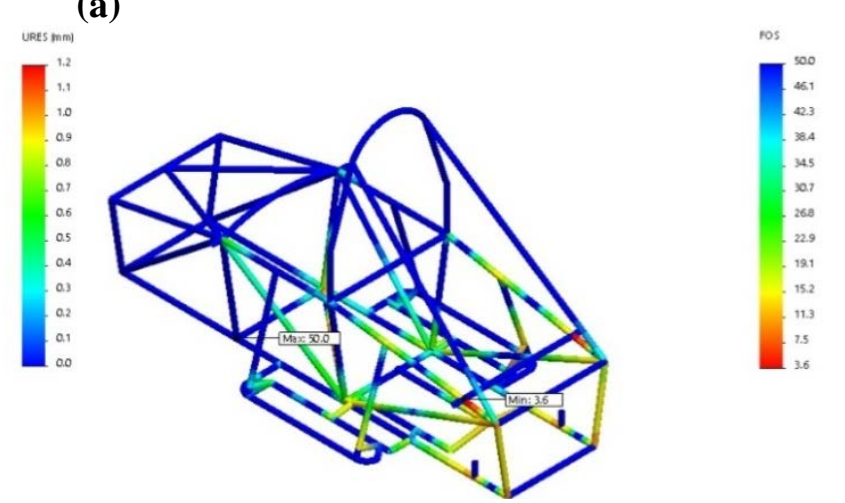

(c)

Gambar 7. Hasil stress Analysis pada beban statis chassis,

(a) Tegangan, (b) Defleksi, (c) FOS

\section{Stress Analysis Chassis untuk Beban Tumbukan}

Tegangan maksimum pada chassis dengan material JIS G 3445 adalah 91,6 N/mm² (Mpa) pada element 8838 atau terletak pada posisi depan chassis yang terkena gaya saat bertumbukan. Sedangkan tegangan minimum yang terjadi pada chassis sebesar $0 \mathrm{~N} / \mathrm{mm}^{2}$ (Mpa) pada element 4060 (Gambar 8a). 
Pada Gambar 8b dapat dilihat defleksi maksimum pada chassis dengan material JIS G 3445 sebesar 0,61 mm pada node 8761 atau terletak pada posisi depan chassis yang terkena gaya saat bertumbukan. Sedangkan defleksi minimum yang didapat sebesar $0 \mathrm{~mm}$ pada nodal 134 .

Pada Gambar 8c dapat dilihat faktor keamanan maksimum pada chassis dengan material JIS G 3445 adalah 50 pada node 74 atau terletak pada posisi yang tidak terkena gaya sedikitpun. Sedangkan faktor keamanan minimum yang terjadi pada chassis sebesar 2,1 pada node 8761 sehingga material dapat digunakan.
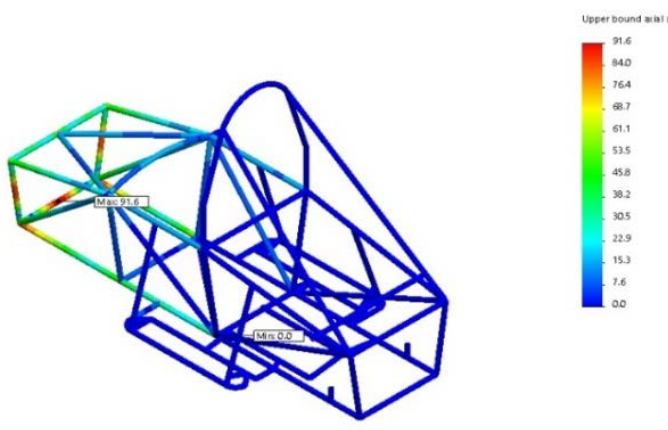

(a)

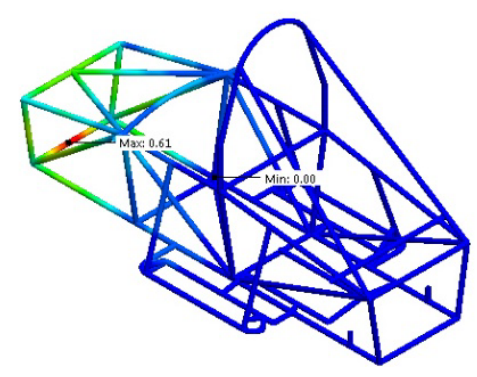

(b)

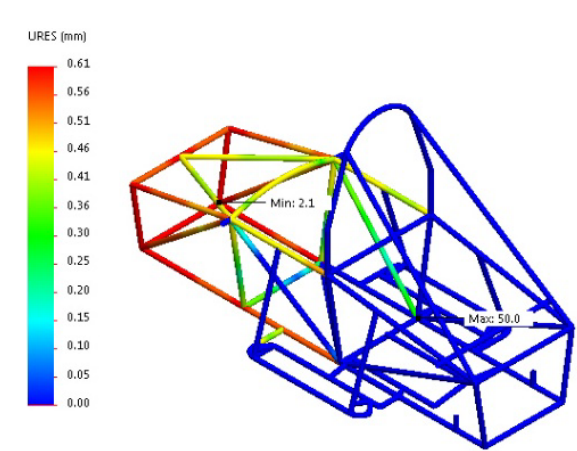

(c)

Gambar 8. Hasil stress Analysis pada beban tumbukan chassis, (a) Tegangan,

(b) Defleksi, (c) FOS

\section{Resume Hasil Perancangan}

Dari hasil analisis tegangan maka ukuran maupun jenis material yang digunakan dapat diketahui resume material yang diperlukan adalah sebagai berikut:

Material

Ukuran Bahan Pipa

Dimensi (PxLxT)

Wheelbase

Jarak Antar Ban

Coating standard

Massa Properties
: JIS G 3445 Steel dengan spesifikasi STKM 11

: Diameter 25,4 mm dengan tebal $2 \mathrm{~mm}$ sebanyak 18 meter, Diameter $19,05 \mathrm{~mm}$ dengan tebal 1,6 mm sebanyak 12 meter dan Plat dengan tebal $3 \mathrm{~mm}$ sebanyak $1 \mathrm{~m}^{2}$.

: $1800 \mathrm{~mm}$ x $800 \mathrm{~mm}$ x $1000 \mathrm{~mm}$

: $1100 \mathrm{~mm}$

: $1300 \mathrm{~mm}$

: Standar ISO 12944-C2Dengan bahan Zinc phosphate epoxy tebal $80 \mu \mathrm{m}$, Micaceous iron acrylic tebal $80 \mu \mathrm{m}$

: Mass $=35.725,67$ grams, Center of mass: (millimeter) $\mathrm{X}=963,83, \mathrm{Y}=190,47, \mathrm{Z}=-200.00$

\section{SIMPULAN}

Hasil Analisis beban statik dengan bahan JIS G 3445, stress maksimum sebesar 53,4 Mpa, simpangan maksimum sebesar $1,2 \mathrm{~mm}$, safety factor sebesar 3,6. Sedangkan untuk beban 
tumbukan, stress maksimum sebesar 91,6 Mpa, simpangan maksimum sebesar 0,61 $\mathrm{mm}$, safety factor sebesar 2,1. Sehingga Chassis sudah memiliki safety factor diatas 2 sesuai dengan kriteria perancangan.

Dimensi chassis yang dirancang adalah $1800 \mathrm{~mm}$ x $800 \mathrm{~mm} \times 1000 \mathrm{~mm}$, dengan mengacu kepada regulasi chassis sudah termasuk kepada kategori baik dimana posisi rollbar harus berada 5 cm diatas helm pengemudi dan lebar maksimum yaitu 120-140 cm. Ukuran bahan yang akan digunakan masing-masing berukuran: Diameter 25,4 $\mathrm{mm}$ dengan tebal $2 \mathrm{~mm}$ sebanyak $18 \mathrm{~m}$, Diameter 25,4 mm dengan tebal 1,4 mm sebanyak $6 \mathrm{~m}$, Diameter 19,05 mm dengan tebal $1,6 \mathrm{~mm}$ sebanyak $12 \mathrm{~m}$ dan plat dengan tebal $3 \mathrm{~mm}$ sebanyak $1 \mathrm{~m}^{2}$.

Massa chassis yang didapat dari software SolidWorks yaitu 35,7 kg telah memenuhi target sebesar di bawah $27 \mathrm{~kg}$. Coating menggunakan standar ISO 12944-C2 dengan bahan zinc phosphate epoxy tebal $80 \mu \mathrm{m}$ dan micaceous iron acrylic tebal $80 \mu \mathrm{m}$.

\section{DAFTAR PUSTAKA}

[1]. C.C. Chan, 2002, The state of the art of electric and hybrid vehicle, Proceedings of the IEEE 90(2): 247 - 275 Transactions on Vehicular Technology Journal, diakses dari halaman web: www.researchgate.net pada tanggal 10 Februari 2016.

[2]. Keith J. Wakeham, 2009, Introduction to Chassis Design, Newfoundland and Labrador: Memorial University.

[3]. Fadila, Ary, 2012, Analisis Simulasi Struktur Chassis Mobil Mesin, USU Berbahan Besi Struktur Terhadap Beban Statik Dengan Menggunakan Perangkat Lunak Ansys 14, (ISSN 2338-1035), Universitas Sumatera Utara.

[4]. Andersson, Carl Eurenius, 2009, "Analysis of Composite Chassis", The Department of Applied Mechanics, Division of Vehicle Engineering and A utonomous Systems, Chalmers University of Technology, Göteborg, Sweden.

[5]. Revserve, 2013, Frame Material: Steel, Aluminium, Titanium, Carbon Fiber diakses dari halaman web: http://cyclest.blogspot.co.id/2013/01/frame-material-steelaluminium-titanium.html pada tanggal 10 Februari 2016.

[6]. Polban, 2015, Regulasi Kompetisi Mobil Listrik Indonesia VII (KMLI VII), 2015, Politeknik Negeri Bandung.

[7]. Dobrovolsky . V, 1988, Machine Elements, Foreign Languages Publishing House, Moscow.

[8]. David, G Ulman, 2010, The Machanical Design Process, $4^{\text {th }}$ edition.

[9]. Kiran Ghodvinde, 2S. R.Wankhade 2014, Structural Stress Analysis of an Automotive Vehicle Chassis, International Journal on Mechanical Engineering and Robotics (IJMER), ISSN (Print): 2321-5747, Volume-2, Issue-6 2014.

[10]. Gerhal. Pahl wolfing Beitz, 1984, Engineering Design, design council London 1984. 